\title{
Effectiveness of Population Data Application Implementation in Kresek Village, Wungu Sub-District, Madiun Regency
}

\author{
Andi Rahman Putera ${ }^{1}$, Eka Resty ${ }^{l}$, Benny Agus $S^{1}$, Ilham Prihantono ${ }^{1}$ \\ ${ }^{1}$ Universitas PGRI Madiun \\ andirahmanputera@unipma.ac.id
}

\begin{abstract}
Population data processing conducted in Kresek Village, Wungu Sub-District, Madiun District is still manual. Data processing that has been used so far is the Excel application. This, causing data processing requires not a little time and quite a long time. With a system that has long data storage is not safe, especially in the long term. To overcome the problems related to population data, it is designed an application to process the data more easily and safely. The purpose of this study was to determine the effectiveness of the previously designed application of population data in Kresek Village. The study was conducted in Kresek Village, Wungu Sub-District, Madiun Regency. Respondents of this study were 2 Kresek Village officers as users. The analytical method used is descriptive analysis using data from interviews with respondents. Evaluation analysis is carried out to explain the new system that has been implemented. Based on the results of the study, it can be concluded that the application that has been designed is in accordance with the wishes of the Kresek village office. This application is able to ease the workload of village officials so that population data processing is more effective and efficient.
\end{abstract}

Keywords: Effectiveness, Population Data Application

\section{Introduction}

Based on Law No. 24 of 2013 article 1 point 9 states that population data is individual data and/or aggregate data that is structured as a result of population registration and civil registration activities. Population data is also one important thing in administration in this country, especially in the villages. Population data processing conducted in Kresek Village, Wungu Sub-District, Madiun Regency is still manual. Data processing that has been used so far is the Excel application. This will cause data processing requires not a little time and quite a long time. With a system that has long data storage is not safe, especially in the long term.

Many related studies that solve complex problems using the help of systems, both intelligence systems [1]-[4] or information systems[5]-[10]. The village needs a system that is able to process the data more easily and safely. One of them is by creating a system that will be able to process population data information such as data collection on population data, family card data, transfer documents, death certificates, birth certificates, and domicile letters. Starting from the above problem, it is necessary to do a needs analysis in Kresek village, Wungu Sub-District, Madiun Regency. It is expected that this system will help the process easier and faster and can also assist in the search and processing of population data needed in Kresek Village.

To overcome the problems that occur, a research is conducted which aimed to provide a solution to the Kresek Village in processing population data, namely by creating a WebBased Population Data Application. This study focuses on analyzing the effectiveness of population data applications that have been implemented previously. The new system in processing data and information will change better than the old system. This population data information system can display more accurate data quickly and precisely in data information processing, especially in population data collection so that it can bring progress in population services in Kresek Village. 


\section{Rudimentary}

The definition of resident and population according to Law Number 52 of 2009 on the Development of Population and Family Development in article 1 are: 1) Residents are Indonesian citizens and foreigners residing in Indonesia; 2) Population is matters relating to the number, structure, growth, distribution, mobility, dissemination, quality, and conditions of welfare that concern the politics, economy, social culture, religion, and environment of the local resident [11][12]. Population data is data about citizens who live in certain areas relating to the number, structure, growth, distribution, mobility, dissemination, quality, and conditions of welfare that concern the political, economic, social, cultural, religious and local environment.

PHP is one side server specifically designed for web applications. PHP is inserted between HTML languages, and because the language is server side, the PHP language will be executed by the server, so that the results sent to the browser are finished in HTML, and the PHP code will not be visible. PHP is Open Source Product. So, you can change the source code and distribute it freely [13]. Previous research conducted by Setiawan (2016) showed the level of satisfaction of Gondomanan Sub-District and Village Office employees. Village officers stated that they are satisfied with the information system that has been made because it is very easy to use and not too heavy. Therefore, this research needs to be performed in Kresek Village, so that population data processing is easier and safer [14].

\section{Research Methodology}

This activity used several quantitative studies. The study was conducted in Kresek Village, Wungu Sub-District, Madiun Regency. Respondents of this study were 2 Kresek Village Officers as users/admin. The analytical method used was descriptive analysis by using data from interviews with respondents. The method of conducting research can be described as follows:

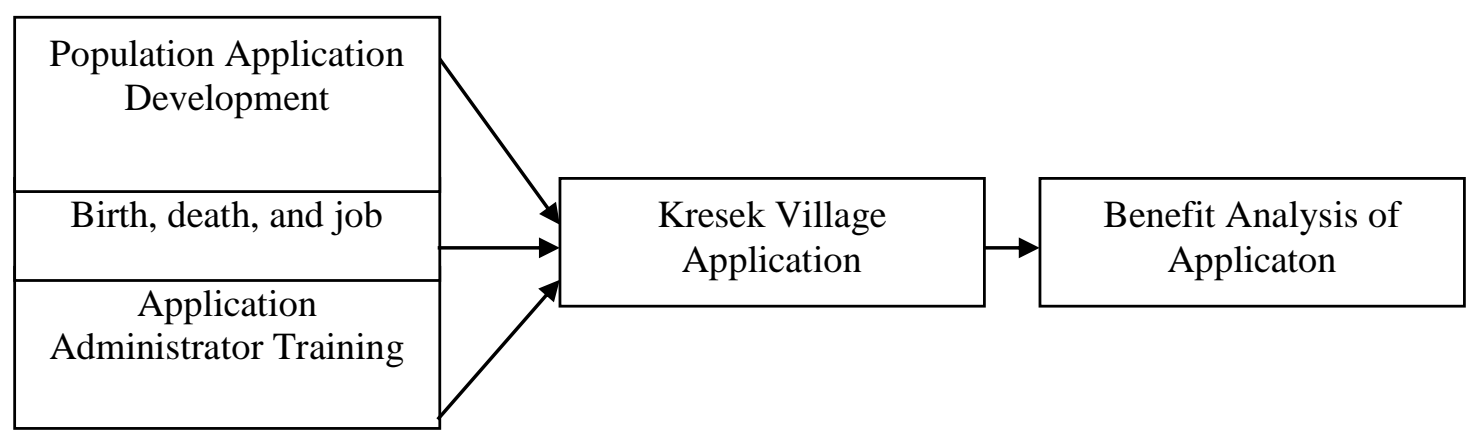

Figure 1. The analytical method

From the scheme above, it can be explained that research activities have five focus activities, namely:

1. Village Application Development

Community service activities with Kresek village partners began with an analysis of the needs of Kresek Village which related to information technology. Preliminary research indicated that Kresek Village required information technology in the form of village application to determine the population of Kresek village.

2. Population data collection

Population data in Kresek Village, it is necessary to map the location of the population that will have a roadmap for each population location to facilitate Kresek Village Officers. 


\section{Application Administrator Development}

For the purposes of managing and maintaining the application, training for application managers is needed. The application manager has the duty to monitor and update information related to population.

4. Village Population Application Monitoring

To achieve the goal of community service with Kresek village partners, it is necessary to periodically monitor the use of village applications. Monitoring is used as an evaluation and improvement material for the future.

5. Benefit Analysis of Application

The researcher also carried out the benefits analysis of the village population application, which later this analysis could be used as an output of community service activities with the Kresek village partners.

This study focused on the fifth step, namely benefits analysis of village population application.

\section{Result and Discussion}

This research is focused on the utilization of population data application. This application is used by village officers in processing population data, such as family data, correspondence, etc. At first, users (village officers) still did not understand how to process population data more easily and efficiently. After the application is developed, village officers can understand and know how to manage village population data in a practical and easy way. Furthermore, this study also provides information about the effectiveness of the application. The effectiveness of the application is obtained from the evaluation after the implementation of the application. Evaluation was carried out by conducting trials and direct interviews with two village officers as users in Kresek Village, Wungu Sub-District, Madiun Regency.

In general, the success rate of making the application of village population data is considered successful, although there are several things that are subject to evaluation. This evaluation material is obtained from the results of interviews with users. The interview results are described as follows. (1) Based on the trials carried out, the population data application system runs well and has enough functions that can be used for processing population data. The system flow is good and not confusing. (2) The features, for now, are sufficient, but it is better to add more features such as other correspondence (domicile certificate, business certificate, good conduct certificate, etc.), and (3) added with population data archive application.

\section{Conclusion}

Based on the results of the study, it can be concluded that the application of village population data is useful in processing population data effectively and efficiently. Application of population data at the Kresek Village office is in accordance with the wishes of the village office. Based on these conclusions, it is suggested several things regarding the application as follows:

a. There needs development in terms of appearance and completeness of the program

b. Population Data Applications in Kresek Village based on web applications can be developed as an online web.

\section{References}

[1] Sumijan, A. P. Windarto, A. Muhammad, and Budiharjo, "Implementation of Neural Networks in Predicting the Understanding Level of Students Subject," Int. J. Softw. Eng. Its Appl., vol. 10, no. 10, pp. 189-204, 2016.

[2] B. Supriyadi, A. P. Windarto, T. Soemartono, and Mungad, "Classification of natural disaster prone areas in Indonesia using K-means," Int. J. Grid Distrib. 
Comput., vol. 11, no. 8, pp. 87-98, 2018.

[3] R. Rahim et al., "Enhanced pixel value differencing with cryptography algorithm," in MATEC Web of Conferences 197, 2018, vol. 3011, pp. 1-5.

[4] A. P. Windarto, "Implementation of Data Mining on Rice Imports by Major Country of Origin Using Algorithm Using K-Means Clustering Method," Int. J. Artif. Intell. Res., vol. 1, no. 2, pp. 26-33, 2017.

[5] V. M. Athawale and S. Chakraborty, "A comparative study on the ranking performance of some multi-criteria decision-making methods for industrial robot selection," Int. J. Ind. Eng. Comput., vol. 2, no. 4, pp. 831-850, 2011.

[6] A. P. W. Budiharjo and A. Muhammad, "Comparison of Weighted Sum Model and Multi Attribute Decision Making Weighted Product Methods in Selecting the Best Elementary School in Indonesia," Int. J. Softw. Eng. Its Appl., vol. 11, no. 4, pp. 6990, 2017.

[7] L. Y. Chen and T. C. Wang, "Optimizing partners' choice in IS/IT outsourcing projects: The strategic decision of fuzzy VIKOR," Int. J. Prod. Econ., vol. 120, no. 1, pp. 233-242, 2009.

[8] A. V. Devadoss and M. Rekha, "A New Intuitionistic Fuzzy ELECTRE II approach to study the Inequality of women in the society," Glob. J. Pure Appl. Math., vol. 13, no. 9, pp. 6583-6594, 2017.

[9] C. Hsu, J. Goh, and P. Chang, "Development of Decision Support System for House Evaluation and Purchasing," World Acad. Sci., vol. 6, no. 5, pp. 572-577, 2012.

[10] A. Wanto et al., "Levenberg-Marquardt Algorithm Combined With Bipolar Sigmoid Function To Measure Open Unemployment Rate In Indonesia," Int. Conf. Comput. Environ. Agric. Soc. Sci. Heal. Sci. Eng. Technol. (3rd ICEST), vol. 3, no. $1,2018$.

[11] D. V. Chulkov, "On the Role of Switching Costs and Decision Reversibility in Information Technology Adoption and Investment," J. Inf. Syst. Technol. Manag., vol. 14, no. 3, pp. 309-321, 2017.

[12] Y. H. Almamary, A. Shamsuddin, and N. A. A. Hamid, "The impact of management information systems adoption in managerial decision making: a review," Manag. Inf. Syst., vol. 8, no. 4, pp. 010-017, 2013.

[13] Republik Indonesia. 1971. Undang-Undang Nomor 7 Tahun 1971 tentang Ketentuan-Ketentuan Pokok Kearsipan. Jakarta: Sekretariat Negara.

[14] Setiawan, D.B.B. "Perancangan Aplikasi Sistem Informasi Kependudukan di Kecamatan Gondomanan". Jurnal Informatika UPGRIS, vol 2, no. 2, (2016). pp 113 118

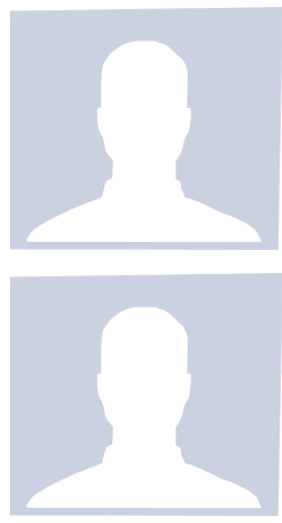

\section{Authors}

$1^{\text {st }}$ Author

Andi Rahman Putera

Universitas PGRI Madiun

andirahmanputera@unipma.ac.id

$2^{\text {nd }}$ Author

Eka Resty

Universitas PGRI Madiun 


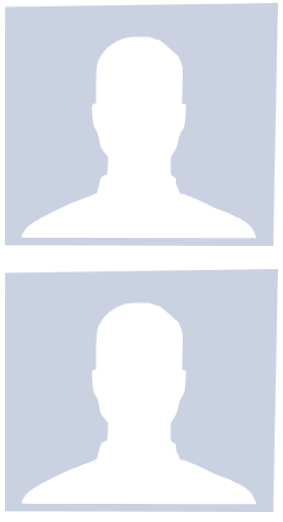

$3^{\text {rd }}$ Author

Benny Agus $S$

Universitas PGRI Madiun

$4^{\text {rd }}$ Author

Ilham Prihantono

Universitas PGRI Madiun 